\title{
Клінічна та морфологічна характеристика пейсмейкера хронічного панкреатиту
}

\author{
О. Є. Каніковський, І. В. Павлик, І. В. Олійник
}

Вінницький національний медичний університет імені М. І. Пирогова

\section{Clinical and morphological characteristic of the chronic pancreatitis pacemakers}

\author{
O. E. Kanikovskyi, I. V. Pavlyk, I. V. Oliinyk \\ Vinnytsya National Medical University named after M. I. Pyrogov
}

\section{Реферат}

Мета. Клінічно та морфологічно обгрунтувати поняття пейсмейкера хронічного панкреатиту (ХП).

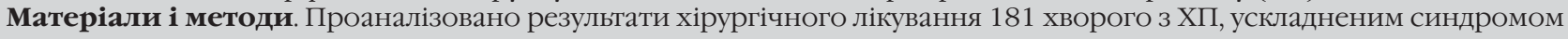
панкреатичної гіпертензії.

Результати. 3 больовим синдромом типу В, що опосередковано вказує на тотальний тяжкий фіброз підшлункової залози (П3), госпіталізовані 24,5\% пацієнтів. Клінічно у всіх цих хворих виявлені множинні стриктури головної протоки П3, інструментально - тканинний тиск спротиву (ТТС) понад 26,7 кПа (200 мм рт. ст.) та гістологічно - площа сполучнотканинних полів сягала $(81,4 \pm 6,62) \%$. Таким чином, пейсмейкером ХП слід вважати стриктуру - зону максимального фіброзу та кальцеутворення головної протоки ПЗ і, що є основним, проток другого та третього порядків. Головка ПЗ була пейсмейкером ХП тільки у 83,8\% спостережень, перешийок або тіло та хвіст П3 - у 16,2\%.

Висновки. Ключовим у хірургічному лікуванні ХП є широке висічення стриктури (зони фіброзу) П3, що забезпечує виконання комбінованої локальної резекції ПЗ за Frey-Izbicki, після якої частота виникнення рецидиву панкреатичної гіпертензії менша на $11,1 \%$.

Ключові слова: пейсмейкер хронічного панкреатиту.

Abstract

Objective. To substantiate a concept of a chronic pancreatitis (CHP) pacemaker.

Materials and methods. Results of surgical treatment in 181 patients, suffering CHP, complicated by pancreatic hypertension syndrome, were analyzed.

Results. There were $24.5 \%$ of the patients, admitted to hospital and suffering the pain syndrome type B, which indicates indirectly on total severe pancreatic fibrosis. In all the patients the multiple strictures of the main pancreatic duct were revealed clinically, as well as the tissue-instrumental pressure of resistance more than $26.7 \mathrm{kPa}(200 \mathrm{~mm} \mathrm{Hg})$ and histologically - a square of the connective-tissue fields - was up to $(81.4 \pm 6.62) \%$. Thus, a stricture ought to be regarded as the CHP pacemaker - a zone of maximal fibrosis and calcium-creation in the main pancreatic duct, which is a principal one, and those of the second and third orders. Pancreatic head have served as the CHP pacemaker in $83.8 \%$ observations only, while the pancreatic neck and body - in $16.2 \%$. Conclusion. The key factor in surgical treatment of CHP is a wide excision of pancreatic stricture (zone of fibrosis), providing performance of combined local pancreatic resection in accordance to Frey-Izbicki procedure with the occurrence rate for the pancreatic hypertension recurrence lesser than $11.1 \%$.

Keywords: the chronic pancreatitis pacemaker.

Основною причиною зростання захворюваності на ХП $€$ зміна способу життя населення [1]. Пацієнтів, як правило, госпіталізують з клінічними проявами кінцевої форми розвитку ХП, коли вони потребують хірургічного лікування. Базовим принципом хірургічного лікування таких пацієнтів є ліквідація так званого пейсмейкера ХП.

Загальновизнаними патоморфологічними критеріями пейсмейкера ХП є наявність запального інфільтрату в головці ПЗ, який характеризується тканинним некрозом незначних розмірів, невеликими кістозними порожнинами головки ПЗ, псевдокістами, стенозом загальної жовчної протоки та головної протоки ПЗ, престенотичним розширенням та компресією ретропанкреатичних судин (ворітної печінкової вени) [2].

Мета дослідження: клінічно та морфологічно обгрунтувати поняття пейсмейкера ХП.

\section{Матеріали і методи дослідження}

У хірургічній клініці медичного факультету № 2 Університету протягом 2000 - 2018 рр. проведено хірургічне лікування 181 хворому з ХП, ускладненим синдромом панкреатичної гіпертензії. Чоловіків було 138, жінок - 43, середній вік пацієнтів - $(46,0 \pm 13,7)$ року. Віком від 30 до 59 років було 73,4\% хворих.

За етіологічними чинниками згідно з класифікацією TIGAR-O [3] у 162 (90\%) пацієнтів ХП виник після перенесеного гострого панкреатиту (ГП), у 172 (95\%) відмічено токсичний вплив алкоголю, причому 18 із них не вказали в анамнезі на перенесений ГП, у 2 пацієнтів ХП виник після хіміотерапії.

Згідно з класифікацією Büchler (2009) [3] «В» стадію ХП спостерігали у 41 (22,65\%) хворого, «С» стадію - у 140 (77,35\%), серед них панкреатогенний цукровий діабет ма- 
ли 38 хворих. Відповідно до Марсельсько-Римської класифікації ХП (1989) [2] кальцифікуючу форму діагностовано у 21 хворого, обструктивну - у 34, запальну - у 2, фіброз П3 - у 12, ретенційні і псевдокісти - у 112. Супутні захворювання констатовано у 152 (83,9\%) хворих.

Усім хворим під час виконання оперативного втручання визначали внутрішньопротоковий тиск за допомогою оригінального манометра (Прилад для вимірювання тиску в порожнистих органах. Пат. України № 59204 від 10.05.2011р.). Також усім хворим визначали ТТС за допомогою апарата Stryker preasure monitor.

У 148 хворих виконали трансабдомінальну оперативну корекцію панкреатичної гіпертензії. У 53 хворих застосували мініінвазивні оперативні втручання, якими обмежилися у 32 (60,3\%) хворих, а у 21 (39,7\%) хворого їх доповнили стандартними трансабдомінальними методами хірургічної корекції [4].

\section{Результати та іх обговорення}

Основним клінічним проявом ХП є больовий синдром, для градації якого важливі такі принципи: постійний чи епізодичний больовий синдром; зникає під медикаментозним впливом чи нi. Rudolf M. Ammann і співавтори виділили больовий синдром типу A - епізодичний сильний біль з наявними безбольовими періодами і типу В - постійний біль, який епізодично посилюється настільки, що виникає потреба у госпіталізації хворого [5, 6.

При кальцифікуючому ХП спостерігали біль типу В у 5 хворих; обструктивному ХП - біль типу А у 4 хворих 3 ізо- льованими стриктурами і типу В у 8 хворих: у 1 була ізольована стриктура головної протоки ПЗ, у 7 - множинні; фіброзі - біль типу А у 1 і типу В у 1 хворого; кістах ПЗ - біль типу А у 26 хворих з малими або середніх розмірів неускладненими кістами і типу В у 17 хворих: у 5 - 3 інфікованими і у 12 - 3 гігантськими кістами.

При ускладненому ХП біль типу В спостерігали у 1 хворого $з$ непрохідністю дванадцятипалої кишки (ДПК) і у 5 хворих з абсцесами ПЗ; типу А - у 7 хворих з холестазом і у 8 хворих $з$ асцитом.

Основними морфологічними проявами ХП є атрофія та фіброз ПЗ $[2,3]$. Для оцінки ступеня фіброзу ПЗ використовують ефективний метод визначення показника ТТС.

У хворих з обструктивним ХП та наявністю стриктури в головці ПЗ ТТС був найвищим саме в ділянці стриктури - понад 26,7 кПа (200 мм рт. ст.), тоді як в інших ділянках ПЗ він зменшувався до 13,3 кПа (100 мм рт. ст.) і нижче (табл. 1). У всіх пацієнтів у місці стриктури гістологічно підтверджено IV стадію фіброзу ПЗ і відмічено достовірну кореляцію між показником ТТС та стадією фіброзу П3. Найбільш виражений фіброз був у ділянці стриктури ПЗ - пейсмейкера ХП.

Як видно із таблиці 1, головка ПЗ була втягнута в патологічний процес у 31 (83,8\%) хворого, тобто головка ПЗ не завжди була пейсмейкером ХП, у 6 (16,2\%) хворих пейсмейкером ХП був перешийок (4) або тіло і хвіст (2) ПЗ. Загалом ураження дистальних відділів ПЗ спостерігали у 37,8\% хворих.

Із 16 хворих із кальцифікуючим ХП тотальний калькульоз спостерігали у 8 (50,0\%), ізольоване ураження голов-

\begin{tabular}{|c|c|c|c|c|c|c|c|}
\hline \multirow{2}{*}{ Локалізація стриктури ПЗ } & \multicolumn{2}{|c|}{ Число хворих } & \multicolumn{4}{|c|}{ ТТС у ділянках ПЗ, кПа (мм рт. ст.) } & \multirow{2}{*}{$p$} \\
\hline & абс. & $\%$ & головка & перешийок & тіло & хвіст & \\
\hline \multicolumn{8}{|l|}{ Ізольована стриктура } \\
\hline головки & 3 & 8,1 & $\begin{array}{c}26,7 \pm 0 \\
(200 \pm 0)\end{array}$ & $\begin{array}{l}16,0 \pm 3,3 \\
(120 \pm 25)\end{array}$ & $\begin{array}{c}10,7 \pm 3,0 \\
(80 \pm 23)\end{array}$ & $\begin{array}{c}10,0 \pm 3,4 \\
(72 \pm 27\end{array}$ & 0,0005 \\
\hline перешийка & 4 & 10,8 & $\begin{array}{r}21,3 \pm 2,1 \\
(160 \pm 15)\end{array}$ & $\begin{array}{c}26,7 \pm 0 \\
(200 \pm 0)\end{array}$ & $\begin{array}{l}21,0 \pm 2,9 \\
(158 \pm 22)\end{array}$ & $\begin{array}{l}16,0 \pm 2,0 \\
(120 \pm 15)\end{array}$ & 0,0006 \\
\hline великого сосочка ДПК & 6 & 16,2 & $\begin{array}{c}26,7 \pm 0 \\
(200 \pm 0)\end{array}$ & $\begin{array}{l}13,3 \pm 2,0 \\
(100 \pm 15)\end{array}$ & $\begin{array}{l}8,0 \pm 1,6 \\
(60 \pm 12)\end{array}$ & $\begin{array}{l}6,9 \pm 1,3 \\
(52 \pm 10)\end{array}$ & 0,0001 \\
\hline \multicolumn{8}{|l|}{ Множинні стриктури } \\
\hline головки і перешийка & 8 & 21,6 & $\begin{array}{c}26,7 \pm 0 \\
(200 \pm 00\end{array}$ & $\begin{array}{c}26,7 \pm 0 \\
(200 \pm 0)\end{array}$ & $\begin{array}{l}22,0 \pm 2,9 \\
(165 \pm 22)\end{array}$ & $\begin{array}{l}17,0 \pm 2,0 \\
(128 \pm 15)\end{array}$ & 0,00068 \\
\hline головки & 6 & 16,2 & $\begin{array}{c}26,7 \pm 0 \\
(200 \pm 0)\end{array}$ & $\begin{array}{l}22,0 \pm 3,2 \\
(165 \pm 24)\end{array}$ & $\begin{array}{l}19,3 \pm 2,3 \\
(145 \pm 17)\end{array}$ & $\begin{array}{l}16,0 \pm 1,3 \\
(120 \pm 10)\end{array}$ & 0,0006 \\
\hline тіла і хвоста & 2 & 5,4 & $\begin{array}{l}18,0 \pm 2,0 \\
(135 \pm 15)\end{array}$ & $\begin{array}{l}19,3 \pm 1,7 \\
(145 \pm 13)\end{array}$ & $\begin{array}{c}26,7 \pm 0 \\
(200 \pm 0)\end{array}$ & $\begin{array}{c}26,7 \pm 0 \\
(200 \pm 0)\end{array}$ & 0,0005 \\
\hline Тотальне ураження & 8 & 21,6 & $\begin{array}{c}26,7 \pm 0 \\
(200 \pm 0)\end{array}$ & $\begin{array}{c}26,7 \pm 0 \\
(200 \pm 0)\end{array}$ & $\begin{array}{c}26,7 \pm 0 \\
(200 \pm 0)\end{array}$ & $\begin{array}{c}26,7 \pm 0 \\
(200 \pm 0)\end{array}$ & - \\
\hline
\end{tabular}

\section{Таблиця 2. Динаміка показників ТТС у хворих з калькульозним ХП}

\begin{tabular}{|c|c|c|c|c|c|c|c|}
\hline \multirow{2}{*}{ Локалізація стриктури ПЗ } & \multicolumn{2}{|c|}{ Число хворих } & \multicolumn{4}{|c|}{ ТТС у ділянках ПЗ, кПа (мм рт. ст.) } & \multirow{2}{*}{$\mathrm{p}$} \\
\hline & абс. & $\%$ & головка & перешийок & тіло & хвіст & \\
\hline Тотальне ураження & 8 & 50,0 & $\begin{array}{c}26,7 \pm 0 \\
(200 \pm 0)\end{array}$ & $\begin{array}{c}26,7 \pm 0 \\
(200 \pm 0)\end{array}$ & $\begin{array}{c}26,7 \pm 0 \\
(200 \pm 0)\end{array}$ & $\begin{array}{c}26,7 \pm 0 \\
(200 \pm 0)\end{array}$ & - \\
\hline \multicolumn{8}{|l|}{ Множинні стриктури } \\
\hline головки & 6 & 37,5 & $\begin{array}{c}26,7 \pm 0 \\
(200 \pm 0)\end{array}$ & $\begin{array}{l}26,0 \pm 0 \\
(195 \pm 4)\end{array}$ & $\begin{array}{l}23,3 \pm 2,4 \\
(175 \pm 18)\end{array}$ & $\begin{array}{l}19,7 \pm 2,4 \\
(148 \pm 18)\end{array}$ & 0,0017 \\
\hline хвоста & 2 & 12,5 & $\begin{array}{l}20,7 \pm 1,6 \\
(155 \pm 12)\end{array}$ & $\begin{array}{l}21,6 \pm 2,4 \\
(162 \pm 18)\end{array}$ & $\begin{array}{c}25,6 \pm 0,8 \\
(192 \pm 6)\end{array}$ & $\begin{array}{c}26,7 \pm 0 \\
(200 \pm 0)\end{array}$ & 0,0001 \\
\hline
\end{tabular}




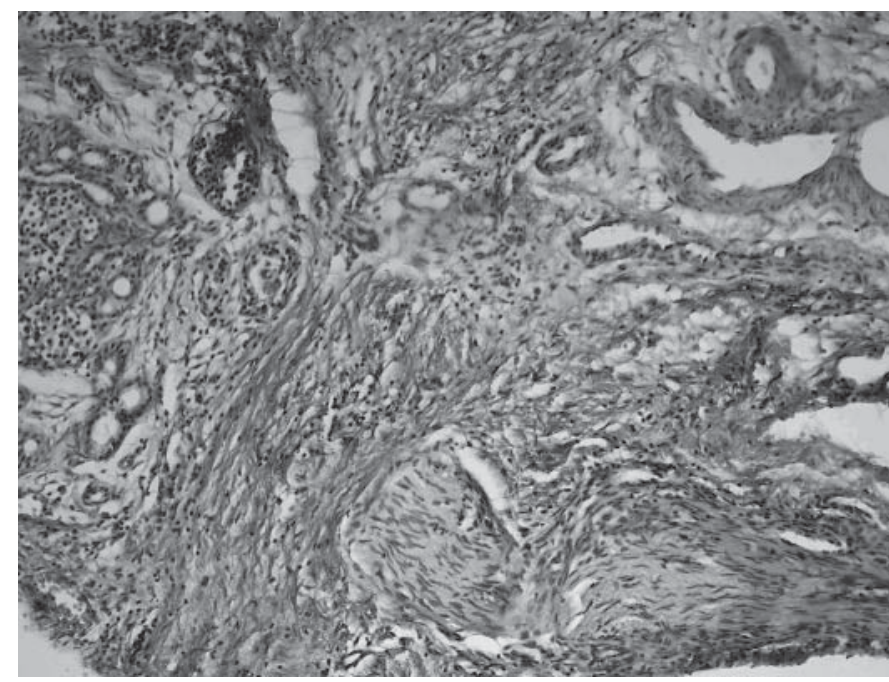

PUc. 1.

Дифузне розростання сполучнотканинних волокон із деформачією артеріол, артерій, міжчасточкового нерва; формування тубулоострівцевих комплексів; IV cmупінъ біброзу.

Забарвлення гематоксиліном та еозином. $36 . \times 200$.

ки П3 - у 6 (37,5\%), хвоста ПЗ - у 2 (12,5\%). У всіх спостереженнях калькульоз поєднувався 3 множинними стриктурами даного відділу ПЗ. У хворих з кальцифікуючим ХП та множинними стриктурами головної протоки ПЗ ТТС був високим - понад 26,7 кПа (200 мм рт. ст.) у всіх відділах ПЗ, вказуючи на ії тотальний фіброз (табл. 2).

Збільшений внутрішньопротоковий тиск зафіксували тільки у 22 (59,5\%) хворих.

Гістологічно ступінь фіброзу ПЗ оцінювали за Stolt (1987). У всіх пацієнтів, яким було показане оперативне втручання, спостерігали IV ступінь - тотальний фіброз, який визначають як значну фіброзну деградацію ПЗ з повною деструкцією екзокринної паренхіми (рис. 1-3). Під час комп'ютерної морфометрії гістологічних зразків площа сполучнотканинних полів становила $(81,4 \pm 6,62) \%$,

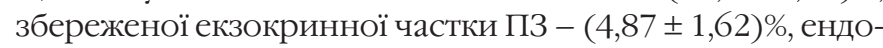
кринної - $(1,92 \pm 0,12) \%$, загальна площа проток - $(6,47$ $\pm 1,12) \%$.

Таким чином, у хворих на момент госпіталізації опосередковано можна оцінити тяжкість фіброзних змін ПЗ за типом больового синдрому. Так, у всіх хворих з калькульозним ХП та множинними стриктурами ПЗ, у яких клінічно визначили тип В больового синдрому, інструментально - ТТС понад 26,7 кПа (200 мм рт. ст.), гістологічно - площу сполучнотканинних полів (81,4 \pm 6,62)\%, що вказувало на IV ступінь фіброзу, спостерігали тотальний тяжкий фіброз ПЗ.

Враховуючи наведені дані, ключовим моментом у лікуванні ХП є широке висічення стриктури (зони фіброзу) ПЗ як пейсмейкера ХП з розкриттям проток другого та третього порядків.

У 14 хворих з кальцифікуючою формою ХП виконали локальну резекцію ПЗ за Fray - Izbicki. У всіх цих хворих констатували множинні стриктури головної протоки П3. У 8 хворих з множинними стриктурами без конкрементів також виконали локальну резекцію ПЗ за Fray - Izbicki.

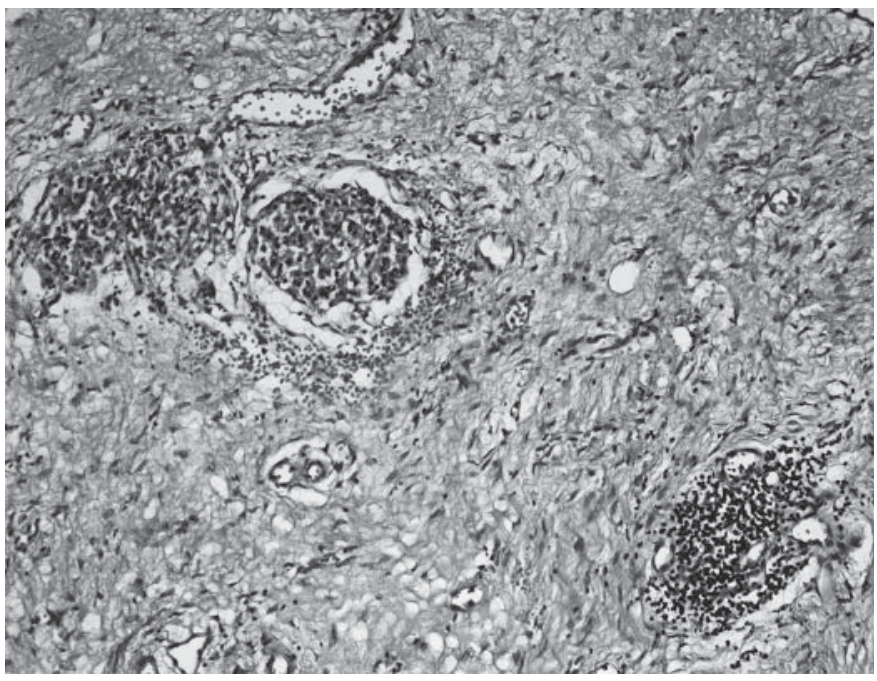

Puc. 2.

Проліферачія міофібробластів із формуванням иироких полів фіброзної тканини; атробія острівиів; осередок хронічного запалення; IV ступінь фіброзу.

забарвлення гематоксиліном та еозином. $36 . \times 200$.

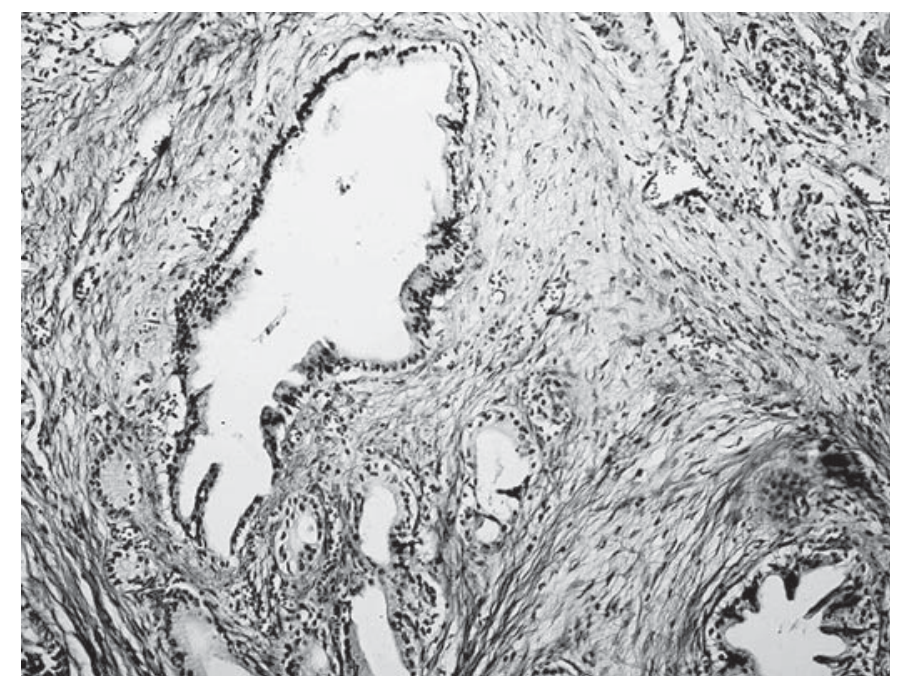

Puc. 3.

Перидуктальне розростання сполучної тканини; кістозно розиирені просвіти міжчасточкових проток з дистрофічними змінами епітелію; IV ступінъ фбіброзу. Забарвлення за ван Гізоном. 3б. ×200.

У 1 хворого з панкреатоплевральною норицею сформували панкреатоєюноанастомоз за Fray - Izbicki з роз'єднанням і висіченням норицевого ходу. У 3 хворих із зовнішньою панкреатичною норицею та показниками внутрішньопротокового тиску $(5,3 \pm 0,2)$ кПа $(560 \pm 25)$ мм вод. ст. і ТТС понад 26,7 кПа (200 мм рт. ст.) після висічення норицевого ходу виконали локальну резекцію ПЗ за Fray - Izbicki.

У 4 хворих із кістою ПЗ, яка мала ретропанкреатичну локалізацію, виконали локальну резекцію ПЗ за Fray Izbicki з цистопанкреатоєюностомією за Т. А. Кадощуком.

У 6 хворих з розширеною протокою ПЗ виконали локальну резекцію ПЗ за Fray. У 4 із цих хворих пейсмейкер локалізувався в головці ПЗ, ім виконали розширену опе- 
рацію Fray; 2 хворим, у яких пейсмейкер локалізувався в області переходу головки в тіло П3, - операцію Fray 3 максимальним висіченням паренхіми в області переходу головки в тіло ПЗ. Розширення оперативного втручання на тканину ПЗ з ТТС менше 16,0 кПа (120 мм рт. ст.) вважаємо недоцільним, оскільки в такому разі різко зростає частота післяопераційних ускладнень, а саме виникнення гострого післяопераційного панкреатиту (спостерігали у 2 хворих).

У 2 хворих разом із внутрішньою декомпресією системи проток ПЗ за наявності ознак біліарної гіпертензії і обтураційної жовтяниці сформували холедоходуоденоанастомоз. У 27 хворих перед трансабдомінальною оперативною корекцією панкреатичної гіпертензії виконали ендоскопічну папілосфінктеротомію. Післяопераційні ускладнення виникли у 3 (9,1\%) хворих. Повторно оперували 1 хвору з приводу післяопераційного гострого некротичного панкреатиту. Ніхто з пацієнтів не помер.

Панкреатодуоденальну резекцію (ПДР) виконували тільки у разі неможливості виключити рак головки ПЗ та ускладнень з боку ДПК, а саме: порушення прохідності ДПК, розширеної або звичайних розмірів протоки з підвищеним або нормальним внутрішньопротоковим та внутрішньотканинним тиском. ПДР виконали у 5 хворих 3 псевдотуморозною формою ХП, ускладненого панкреатичною гіпертензією. У всіх цих хворих не можна було виключити онкологічний процес у головці ПЗ. Результати застосування маркерів СА 19-9, СА 50 та РЕА мали граничний характер, а за даними комп'ютерної томографії в головці ПЗ визначали об'ємне утворення розміром від 2 до 4 см. Післяопераційні ускладнення виникли у 1 хворого. Ніхто з пацієнтів не помер. Серед мініінвазивних оперативних методик використали ендоскопічну папілосфінктеротомію (35 спостережень), ендоскопічну літоекстракцію (3), ендоскопічне назобіліарне дренування (24), ендоскопічну дилатацію головної протоки ПЗ (5), пункцію і дренування під контролем ультрасонографії порожнистих утворень черевної порожнини (9), закриту торакостомію і дренування плевральної порожнини (32), лапароскопічне дренування черевної порожнини (5), адбоміноцентез (22). Усього 53 хворим виконали 135 мініінвазивних оперативних втручань. У 48 (92,0\%) хворих застосували дві і більше мініінвазивних методики. Крім того, у 20 (37,3\%) хворих застосування мініінвазивних методик передувало трансабдомінальним втручанням, а у 6 (9,6\%) хворих їх використали в післяопераційному періоді.

Віддалені результати проаналізовано у 24 хворих протягом 6 - 36 міс. Рецидиву панкреатичної гіпертензії піс- ля застосування методики декомпресії за Fray - Izbicki не констатували. Відповідно до опитувальника SF-36 у хворих, яких оперували з приводу ХП із формуванням панкреатоєюноанастомоза, через 6 міс і більше показник інтенсивності болю становив $(3,2 \pm 0,19)$ бала і був меншим порівняно з передопераційним показником - $(5,3$ $\pm 0,5)$ бала $(\mathrm{p}<0,05)$.

\section{Висновки}

1. Тип В больового синдрому опосередковано вказує на тотальний тяжкий фіброз ПЗ, що підтверджується інструментально - ТТС понад 26,7 кПа (200 мм рт. ст.) та гістологічно - площа сполучнотканинних полів сягає $(81,4 \pm 6,62) \%$.

2. Пейсмейкером ХП слід вважати стриктуру - ділянку максимального фіброзу та кальцеутворення головної протоки ПЗ і, що є основним, проток другого та третього порядків.

3. Головка ПЗ була пейсмейкером ХП тільки у 83,8\% хворих, у 16,2\% він був розміщений ізольовано в перешийку або тілі та хвості ПЗ.

4. Ключовим у лікуванні ХП є широке висічення стриктури (зони фіброзу) ПЗ як пейсмейкера ХП із розкриттям проток другого та третього порядків, що забезпечує виконання комбінованої локальної резекції ПЗ за Frey-Izbicki.

\section{References}

1. Machicado JD, Rebours V, Yadav D. Epidemiology of Chronic Pancreatitis. Pancreapedia: Exocrine Pancreas Knowledge Base. 2016 July;28. Available from:: https://www.pancreapedia.org/reviews/epidemiologyof-chronic-pancreatitis. doi: 10.3998/panc.2016.13.

2. Majumder S, Chari ST. Chronic pancreatitis. Lancet. 2016 May 7;387(10031):1957-66. doi: 10.1016/S0140-6736(16)00097-0.

3. Ito T, Ishiguro H, Ohara H, Kamisawa T, Sakagami J, Sata N, et al. Evidence-based clinical practice guidelines for chronic pancreatitis 2015. Journal of Gastroenterology. 2016;51(2):85-92. doi: 10.1007/s00535015-1149-x.

4. Datta J, Vollmer CM. Advances in Surgical Management of Pancreatic Diseases. Journal of Gastroenterolology of Clinics of North America. 2016;45(1):129-44. doi: 10.1016/j.gtc.2015.10.002.

5. Jawad ZAR, Kyriakides Ch, Pai M, Wadsworth Ch, Westaby D, Vlavianos $\mathrm{P}$, et al. Surgery remains the best option for the management of pain in patients with chronic pancreatitis: A systematic review and meta-analysis. Asian Journal of Surgery. 2017 May;40(3):179-85. doi: 10.1016/j.asjsur.2015.09.005.

6. Anderson MA, Akshintala V, Albers KM, Amann ST, Belfer I, Brand R, et al. Mechanism, assessment and management of pain in chronic pancreatitis: Recommendations of a multidisciplinary study group. Pancreatology. 2016;16(1):83-94. doi: 10.1016/j.pan.2015.10.015. 